\title{
Toxicity of MCPA on non-green potato tuber calli
}

\author{
Francisco P. Peixoto • M. Ludovina Lopes • \\ Vítor M. C. Madeira $\cdot$ Joaquim A. F. Vicente
}

Received: 28 March 2008/Revised: 7 July 2008/ Accepted: 21 August 2008

(C) Franciszek Górski Institute of Plant Physiology, Polish Academy of Sciences, Kraków 2008

\begin{abstract}
Growth of potato tuber calli cells (non-green) is inhibited by 4-chloro-2-methylphenoxyacetic acid (MCPA) as a consequence of perturbation of membrane integrity. MCPA also depresses ATP content with simultaneous increase of ADP and AMP, i.e., the energy charge is severely compromised. Cell redox state is also affected by MCPA, as a function of concentration. Up to $60 \mu \mathrm{M}$, MCPA stimulates glutathione reductase and glutathione transferase, whereas superoxide dismutase and catalase activities are not affected. However, $120 \mu \mathrm{M}$ MCPA inhibits all these activities. Cell death challenged by MCPA is putatively related to disturbance of membrane integrity responsible for mitochondrial uncoupling with decrease of the energy charge and subsequent loss of ions and metabolites.
\end{abstract}

Keywords Herbicide - MCPA - Potato tuber calli . Redox state $\cdot$ Energy charge $\cdot$ Antioxidant enzymes

$\begin{array}{ll}\text { Abbreviations } \\ \text { GST } & \text { Glutathione } S \text {-transferase } \\ \text { CAT } & \text { Catalase } \\ \text { GR } & \text { Glutathione reductase }\end{array}$

Communicated by S. Lewak.

F. P. Peixoto $(\bowtie)$

Chemistry Department, CECAV, University of Trás-os-Montes and Alto Douro, P.O. Box 1013, 5000-911 Vila Real, Portugal e-mail: fpeixoto@utad.pt

M. L. Lopes - J. A. F. Vicente

Department of Botany, IMAR, Interdisciplinary Center of Coimbra, University of Coimbra, 3001-455 Coimbra, Portugal

V. M. C. Madeira

Department of Biochemistry, University of Coimbra, 3004-517 Coimbra, Portugal
SOD Superoxide dismutase

ROS Reactive oxygen species

EDTA Ethylenediamine-tetraacetic acid

MCPA 4-Chloro-2-methylphenoxyacetic acid

\section{Introduction}

2-Methyl-4-chlorophenoxyacetic acid (MCPA) was developed in the 1940s and is a chlorophenoxy herbicide widely used to effectively control a wide variety of broadleaved weeds in cornfilds, grasses, orchards, grapes, flax, sugarcane, pulses, and non-crop areas.

Due to its chemical structure which is similar to that of natural plant hormones (auxins), it causes uncontrolled growth of the meristematae and restrains both DNA and protein synthesis (Fargasova 1994), thereby causing the disruption of basic metabolic processes in plant cells and tissues.

The usual MCPA field dose is 1,000-fold higher than the normal auxin level within plants, which causes extensive cell growth stimulation resulting in the death of the plant (Hopkins 1999).

Toxicological assays in rats show that the liver and the kidneys are the target organs for MCPA. MCPA induces cytochrome P450 isoenzymes in Hep G2 cells; the cytoskeletal components actin and vinculin were dramatically affected by MCPA metabolism cousing protein sulfhydryl groups depletion (Camatini et al. 1998).

Kobal and Budihna (1999) showed that at low concentration $\left(15 \mathrm{mg} \mathrm{kg}^{-1}\right)$ MCPA affects neither the body weight of adult rats and rabbits nor that of their offspring and the weight of inner organs is maintained. However, at higher concentrations $\left(150 \mathrm{mg} \mathrm{kg}^{-1}\right)$ significant changes in 